\title{
Estimation of Cranial Capacity in 20-25 Year Old Population of Madhya Pradesh, a State of India
}

\author{
Estimación de la Capacidad Craneana en la Población de 20 a 25 Años de Edad \\ de Madhya Pradesh, un Estado de la India
}

Vineet Kumar Gohiya; Sudha Shrivatava \& Sarita Gohiya

\begin{abstract}
GOHIYA, V. K.; SHRIVATAVA, S. \& GOHIYA, S. Estimation of cranial capacity in 20-25 year old population of Madhya Pradesh, a state of India. Int. J. Morphol., 28(4):1211-1214, 2010.

SUMMARY: It is known that there exists close relationship between cranial capacity and size of the brain. Several studies have estimated the cranial capacity, which indirectly reflects the brain volume in different populations. The aim of this study was to estimate cranial capacity of a particular age group of population of Madhya Pradesh. This study was carried out on 400 healthy $20-25$ year old (200 male and 200 female) individuals of Madhya Pradesh state of India, by using linear dimensions of head (Lee Pearson's formula). The mean cranial capacity and SD in males \& females were $1380.52 \pm 94.63 \mathrm{cc}$ and $1188.75 \pm 91.16 \mathrm{cc}$ respectively. This study has shown a significant $(\mathrm{p}<0.05)$ difference between male and female population, being higher in males than in females.
\end{abstract}

KEY WORDS: Anthropometry; Cranial capacity; Skull; Sex

\section{INTRODUCTION}

Knowledge of the volume of cranial cavity of either a dry skull or of a living being may be important to the study and comparison of the crania of populations with various fundamental differences like racial, geographic, ethnic, dietary, environmental, etc. (Manjunath, 2002a). Cranial capacity, which is in close correlation with brain volume reflects the racial characteristics \& this has been thought to be one of commonest items in physical anthropological studies (Hwang et al., 1995; Manjunath, 2002a). Most of those available studies have been made on dry skulls using linear dimensions, packing methods or occasionally radiological methods. It is also an indirect approach to evaluate size of the brain (Manjunath, 2002b). A few studies have been made on living subjects (Golalipour et al., 2005). Although a few studies on the estimation of cranial volume do exist in the Indian literature, these studies are based on examination of macerated skull (Manjunath, 2002b; Shukla, 1966; Routal et al., 1984) but hardly any study of cranial capacity based on the examination of living subject. This motivated us to do such type of study in our state.
Henceforth, in the present study an attempt has been made to estimate cranial capacity of living subjects using linear dimensions of head in this state of India.

\section{MATERIAL AND METHOD}

This study was carried out on 400 healthy 20-25 year old (200 males and 200 females) individuals of Madhya Pradesh state of the India, during 2005. All the measurements were taken with the subjects sitting in chair, in relaxed condition and head in the anatomical position. In each subject following linear dimensions of the head were measured.

Maximum head length (L) (Glabella - Inion length).

Maximum head breadth (B) (measured between parietal eminences). 1 and 2 measured with spreading caliper.

Head height $(\mathrm{H})$ (external acoustic meatus to the highest point of the vertex) using an auricular head spanner and sliding caliper.

Assistant Professor, Department of Anatomy, Index Medical College Hospital and Research Centre, Index City, Near Khudel, Nemwar Road, NH 59 A, Indore. (MP), India

** Dr. Mrs. Sudha Shrivatava, Professor Department of Anatomy, MGM Medical College, Indore, (MP), India

**** Dr. Sarita Gohiya, Assistant Professor, Department of Anaesthesiology, Index Medical College Hospital and Research Centre, Index City, Near Khudel, Nemwar Road, NH 59 A, Indore. (MP), India. 
Each measurement was taken to the nearest millimeter at least three times and the average was considered for calculation. The magnitude of cranial capacity was calculated using Lee Pearson's formula (given by Williams et al., 1995; Manjunath, 2002a).

Males: 0.000337(L-11) (B-11) (H-11) +406.01cc Females: 0.000400(L-11) (B-11) (H-11) +206.60cc

The data of each person was recorded \& analyzed by SPSS 17 and MS excel 2007. For comparison of the mean of cranial capacity ' $t$ ' test was used.

\section{RESULTS}

The mean, SD of head length, head breadth and head height of both sexes are mentioned in the table given below. The mean cranial capacity and SD in males and females were $1380.52 \pm 94.63 \mathrm{cc}$ and $1188.75 \pm 91.16 \mathrm{cc}$ respectively. There was a significant difference between genders $(\mathrm{p}<0.05)$. This investigation has shown that the cranial capacity is significantly higher in males than in females.

\section{DISCUSSION}

This study has estimated cranial capacity in male and female population of Madhya Pradesh state of India as 1380.52 $\pm 94.63 \mathrm{cc}$ and $1188.75 \pm 91.16 \mathrm{cc}$ respectively. The finding of this study is lower than Turkman's group in North of Iran and is nearly similar to native Fars group in North of Iran (Golalipour et al., 2005).

The method of measuring the cranial capacity with the aid of water poured into a rubber balloon, which has been lowered into cranial cavity through the foramen magnum was used by various workers. The first effective attempt in this direction was made by Poll (1896).

MacDonell (1904) determined the capacity of the 31 skulls by using very hard dry mustard seeds and also compared
English skulls with Egyptian skulls. He observed that the length, breadth \& capacity of English skulls are much more than that of Egyptian skulls.

Hooton (1926) observed that the racial characteristics are best defined in the skull, cranial capacity being one of the most important parameters for determining the racial difference. Frazer (1946) observed that the adult cranial capacity varies from 1000cc to 1800cc with an average of about 1400cc. Brash (1951) reported that the size of the skull varies considerably in different races of man:

Microcephalic skulls are those with capacity below $1350 \mathrm{cc} \&$ they include the skulls of Andamanese, Veddahs, Australians, Bushmen and Tasmanians.

Mesocephalic skulls range from $1350 \mathrm{cc}$ to $1450 \mathrm{cc}$ and they are found among the following races: American Indians, Chinese and some African Negroes.

Megacephalic skulls are those with a capacity over $1450 \mathrm{cc}$. They are most commonly met with in the more highly civilized races: Mixed Europeans, Japanese, etc.

Chaturvedi \& Harenja (1962) reported that the average cranial capacity in dry skulls of Indian origin was $1296.6 \pm 13.88 \mathrm{cc}$. Hwang et al. reported the cranial capacity to be $1470 \pm 107 \mathrm{cc}$ in male skulls \& $1317 \pm 117 \mathrm{cc}$ in female skulls. Routal et al. observed that the endocranial volume progressively increases with the increase in area of foramen magnum, but after certain limits endocranial volume becomes almost constant irrespective of further rise in area of foramen magnum.

Manjunath (2002b) observed that the mean cranial volume by Lee Pearson's formula was $1152.815 \pm 279.16 \mathrm{cc}$ in males and $1117.82 \pm 99.09 \mathrm{cc}$ in females. By using Spheroidal formula, values were $1169.68 \pm 239.98 \mathrm{cc}$ in males and $1081 \pm 111.6 \mathrm{cc}$ in females.

Golalipour et al. observed that the mean and SD of cranial capacity in Turkman's males and females were $1420.6 \pm 85 \mathrm{cc}$ and $1227.2 \pm 120 \mathrm{cc}$, respectively. The mean and $\mathrm{SD}$ of cranial capacity in native Fars males and females were

Table I. Showing various parameters of the head of 20 - 25 yrs old population of Madhya Pradesh state of India.

\begin{tabular}{lcccc}
\hline \multirow{2}{*}{ Different parameters } & \multicolumn{2}{c}{ Male } & \multicolumn{2}{c}{ Female } \\
\cline { 2 - 5 } & Mean & SD & Mean & SD \\
\hline Maximum head length $(\mathrm{mm})$ & 191.270 & 6.903 & 178.720 & 5.577 \\
Maximum head breadth $(\mathrm{mm})$ & 145.615 & 5.908 & 138.740 & 6.123 \\
Head height $(\mathrm{mm})$ & 130.025 & 7.206 & 125.475 & 6.023 \\
\hline
\end{tabular}


$1369 \pm 142 \mathrm{cc}, 1215.8 \pm 125 \mathrm{cc}$, respectively and this difference was significant.

Acer et al. (2007) estimated the cranial capacity in the male and female students of the Mugla University, Mugla, Turkey. By using linear dimensions of head, the mean cranial capacity and SD in males and females were $1411.64 \pm 118.9$ $\mathrm{cc}$ and $1306 \pm 162.9 \mathrm{cc}$, respectively. There was a significant difference between genders $(\mathrm{p}<0.05)$.
Also, cranial capacity is an indirect approach to evaluate the size of the brain, which has been affected by gender, race, ethnic, geographical, biological and ecological factors (Hooton; Tuli et al., 1995).

We can conclude that cranial capacity and brain size is being affected by the gender of the population as studied here in this region of India.

GOHIYA, V. K.; SHRIVATAVA, S. \& GOHIYA, S. Estimación de la capacidad craneana en la población de 20 a 25 años de edad de Madhya Pradesh, un estado de la India. Int. J. Morphol., 28(4):1211-1214, 2010.

RESUMEN: Se sabe que existe relación entre la capacidad craneana y el tamaño del cerebro. Varios estudios han estimado la capacidad craneana, la que indirectamente refleja el volumen del cerebro en diferentes poblaciones. El objetivo de este estudio fue estimar la capacidad craneana en un grupo de edad específica de la población de Madhya Pradesh. Este estudio fue realizado en 400 sujetos sanos de 20 a 25 años de edad (200 hombres y 200 mujeres) del estado de Madhya Pradesh, India, mediante el uso de las dimensiones lineales de la cabeza (fórmula Lee Pearson). La capacidad craneana media y DS en los hombres y mujeres fue 1380,52 $\pm 94,63$ cc y $1188,75 \pm 91,16$ cc respectivamente. Este estudio demostró una disminución significativa $(\mathrm{p}<0,05)$ entre la población masculina y femenina, siendo mayor en hombres que en mujeres.

PALABRAS CLAVE: Antropometría; Capacidad craneal; Cráneo; Sexo.

\section{REFERENCES}

Acer, N.; Usamaz, M.; Tugay, U. \& Erteki'n, T. Estimation of cranial capacity in 17-26 years old university students. Int. J. Morphol., 25(1):65-70, 2007.

Chaturvedi, R. P. \& Harenja, N. K. Cranial capacity, gnathic index and facial angle in adult human skulls. J. Anat. Soc. India, 11:18-23, 1962.

Brash, J. C. Cunningham's Textbook of Anatomy. $9^{\text {th }}$ ed. New York, Oxford University Press, 1951.

Frazer, J. E. Anatomy of the Human Skeleton. $4^{\text {th }}$ Edition. London, Churchill, 1946.

Golalipour, M. J.; Jahanshaei, M. \& Haidari, K. Estimation of cranial capacity in 17-20 years old in South East of Caspian Sea Border (North of Iran). Int. J. Morphol, 23(4):301-4, 2005.

Hooton, E. A. A method of racial analysis. Science, 44:256, 1926.

Hwang, Y.; Lee, K. H.; Choi B.; Lee, K. S.; Lee, H.Y.; Sir, W. S. et al. Study on the Korean adult cranical capacity. J. Korean Sci., 10:239-42, 1995.

MacDonell, W. R. A study of the variation and correlation of the human skull with special reference to English Crania. Biometrika, 3:191-244, 1904.

Manjunath, K. Y. Estimation of cranial volume in dissecting room cadavers. J. Anat. Soc. India, 51:168-72, 2002a.

Manjunath, K. Y. Estimation of cranial volume an overview of Methologies. J. Anat. Soc. India, 51:85-91, 2002b.

Poll, H. Ein neuer Apparat zur Bestimmung der Schadelkapazitat. Ver. Berl. Ges. Anthropol., 615-20, 1986.

Routal, R. V.; Pal, G. P. \& Bhagwat, S. S. Relationship between endocranial volume and the area of the foramen magnum. J. Anat. Soc. India, 33:145-9, 1984.

Shukla, A. P. A study of cranial capacity and cranial index of Indian skull. J. Anat. Soc. India., 15:31-5, 1966.

Tuli, A.; Choudhry, R.; Agarwal, S.; Anand, C. \& Gary. H. Correlation between craniofacial dimensions and foetal age. J. Anat. Soc. India, 44:1-12, 1995.

Williams, P. L.; Bannister, L. H; Berry, M. M.; Collins, P; Dyson, M.; Dussek, J. E. \& Ferguson, M.W. J. Gray's Anatomy. Soames, R. W. Edn. 38th. London, Churchill Livingstone, 1995. p612. 
GOHIYA, V. K.; SHRIVATAVA, S. \& GOHIYA, S. Estimation of cranial capacity in 20-25 year old population of Madhya Pradesh, a state of India. Int. J. Morphol., 28(4):1211-1214, 2010.

Correspondence to:

Dr. Vineet Kumar Gohiya

Assistant Professor

Department of Anatomy

Index Medical College Hospital and Research Centre

Index City, Near Khudel

Nemwar Road, NH 59 A

Indore. (MP)

452016

INDIA

Email:vkgohiya@gmail.com

Received: $16-05-2010$

Accepted: 03-08-2010 